This is an electronic reprint of the original article. This reprint may differ from the original in pagination and typographic detail.

Author(s): Hyvärinen, Jenni; Laajalahti, Anne; Vos, Marita

Title: $\quad$ Enhancing citizen response to crises through communication : investigating expert views

Year: $\quad 2015$

Version:

Please cite the original version:

Hyvärinen, J., Laajalahti, A., \& Vos, M. (2015). Enhancing citizen response to crises through communication : investigating expert views. International Journal of Emergency Management, 11(4), 302-319. https://doi.org/10.1504/IJEM.2015.074044

All material supplied via JYX is protected by copyright and other intellectual property rights, and duplication or sale of all or part of any of the repository collections is not permitted, except that material may be duplicated by you for your research use or educational purposes in electronic or print form. You must obtain permission for any other use. Electronic or print copies may not be offered, whether for sale or otherwise to anyone who is not an authorised user. 


\title{
Enhancing citizen response to crises through communication - investigating expert views
}

\author{
Jenni Hyvärinen \\ Agora Center \\ University of Jyvaskyla, Finland \\ Email: jenni.m.hyvarinen@jyu.fi \\ Anne Laajalahti \\ Department of Communication \\ University of Jyvaskyla, Finland \\ Email: anne.laajalahti@jyu.fi \\ Marita Vos \\ Agora Center / Department of Communication \\ University of Jyvaskyla, Finland \\ Email: marita.vos@jyu.fi \\ *Corresponding author
}

\begin{abstract}
The purpose of the paper is to clarify how citizen response to crises is currently being enhanced, and how it might be increased, by emergency response organisations in member states of the European Union via communication strategies and tools. Data were gathered via an online questionnaire directed at emergency management and crisis communication experts working in the field of crisis response. The experts were drawn from the database of an international conference. The results indicate that while the importance of involving citizens in crisis response is generally acknowledged, the implementation of such activities is often fragmented. Although some initiatives are under way, coherent structures are lacking. It is suggested that the issue needs structural attention and that such efforts need to include a wide range of emergencies, applying regional and cultural specific approaches adapted to local needs.
\end{abstract}

Keywords: crisis management; community approach; citizen response; crisis communication.

Biographical notes: Jenni Hyvärinen, MA, is a Student recruitment specialist of Student Affairs and Services of the University of Jyvaskyla, Finland. As a doctoral researcher she worked for the EU-funded project Public Empowerment Policies for Crisis Management of Agora Center of the University of Jyvaskyla.

Anne Laajalahti, PhD, is a Postdoc researcher at the Department of Communication of the University of Jyvaskyla, Finland. Her research focuses on interpersonal communication competence in the context of research work and crisis situations.

Marita Vos, PhD, is a Professor of Organizational Communication and PR at the University of Jyvaskyla, Finland. She led several EU-funded projects in the security area, see www.crisiscommunication.fi. Her research centres on multi-actor networks in turbulent environments, including crises and societal issue arenas. 


\section{Introduction}

Authorities cannot solve crisis situations and emergencies alone. The view that communities and citizens should be included in crisis preparedness and within the response network is widely held among both scholars (e.g. Helsloot and Ruitenberg, 2004; Norris et al., 2008) and practitioners (FEMA, 2011b; IFRC, 2011; UNISDR, 2011). In responding to the complex crises that arise today, in which the input of many different actors, including citizens and citizens groups, is essential, smooth cooperation is of paramount importance.

The purpose of this study was to find out how citizen response to crises, by organisations focusing on emergency response or otherwise working in the field of crisis management, is currently being promoted by communication strategies and tools in member states of the European Union. So far, the role of communication in community resilience remains partially undefined (Seeger and Sellnow, 2013).

This study clarifies the views of emergency management and crisis communication experts on the state of the art in enhancing citizen response through communication, how this can be further strengthened, and what are considered best practices. The study contributes to a broader research project on public empowerment policies for crisis management in the European Union, in which citizen viewpoints have also been investigated (e.g. Linnell, 2014) and theoretical work done to create a conceptual framework for future research (Hyvärinen and Vos, 2015). Following this framework, in this paper, crisis management is viewed as co-produced by organisations and citizens. Here the term 'citizens' refers to various societal levels, such as individuals, families, and other groups. In disaster risk reduction, a community approach is called for (Eiser et al., 2012). This is also known as the 'whole community approach', and includes response organisations focusing on emergency management, other relevant organisations, and citizens (FEMA, 2011a). In other words, cooperation across the multi-actor response network includes citizen groups. Citizen response refers to all actions taken by citizens to prepare for and react to crises "with the intent to help themselves or others limit the effects of the disaster or major accident" (Helsloot and Ruitenberg, 2004: 98-99). This paper focuses on emergencies and disasters that may be the result of acts of nature or acts of man, both intended such as terrorism, or unintended such as major accidents and infrastructure failure.

Characterizing crisis response as collaborative action calls for communication activities between emergency response organizations, other organizations involved, and citizens. Scholars have investigated barriers to collaboration. Foremost, this concerns the culture of command and control that exists in many formal response organisations which, in times of crisis, when existing structures collapse, makes it difficult to link up with citizen initiatives and improvise (Dynes, 1994). In addition, research has shown that the myth of a panicprone public often serves as an excuse not to inform and involve citizens (Perry and Lindell, 2003). Scholars have also collated best practices in crisis communication and management that emphasize collaboration with public groups. For example, Seeger (2006) underlines the importance of creating partnerships with the public, while Veil and Husted (2012) emphasize the need for establishing a broad network, including organisational sources, outside agencies and the media, and so forming partnerships to share information and listen to public concerns. The importance of boundary spanners that provide information for collaboration among rescue organisations has been pointed out (Danielsson, 2014); however, exchange of information with public groups similarly helps to build the situational picture and facilitates cooperation with citizens. A multi-level approach is proposed, as citizen response occurs on both the individual and group level 
(Boon et al., 2012). During normal operations, before crises occur, it is important to establish connections with diverse public groups and communities (Veil and Husted, 2012). The importance of social relationships in emergency management has also been underlined in recent studies on information flows involving volunteers (Long et al., 2014), who can be organized, semi-organized, or non-organized individuals (Linnell, 2014).

Guidelines for practice have been set (e.g. FEMA, 2011a; UNISDR, 2011). Additionally, four approaches to crisis preparedness activities aimed at increasing the citizens' capabilities for risk reduction have been proposed (IFRC, 2011): (1) campaigns aiming at a uniform, large-scale impact using standard messages; (2) participatory learning, in which publics are engaged in disaster risk reduction; (3) informal education in communities and schools, involving disseminating standardized messages but with the flexibility to accommodate the needs and concerns of specific local audiences; and (4) formal school-based learning, where a curricular focus on school disaster management and disaster risk reduction requires support for long-term planning and capacity building.

In the literature, the focus has been on community approaches that may also include a variety of media. Participatory approaches involving citizens through local broadcast media have been investigated (Romo-Murphy and Vos, 2014). Furthermore, social media have received much attention in the literature, as a platform for the exchange of information both among citizens and between citizen and response organisations (Palen et al., 2009; Yee et al., 2012). Including citizens in crisis preparedness has been emphasized as a form of stakeholder enabling and public empowerment (e.g. Palenchar and Heath, 2007). In addition, discursive management strategies have been proposed from an ethical perspective, involving people not as objects but rather as subjects in a human-centred discipline of emergency management (Etkin and Timmermans, 2013). However, it has also been suggested by the afore-mentioned authors that community approaches need more attention in practice. Response organizations need to understand how citizens prepare for and react to crisis situations; this calls for investigating citizen behaviour and views. In addition, expert views on how citizen response is currently facilitated by response organizations and how this can be improved, need to be gathered. The latter approach is taken in this paper, which focuses on expert views on how citizen response can be enhanced in practice.

The paper is ordered as follows: section 2 outlines the research method, section 3 describes the participants, section 4 presents the findings and section 5 concludes.

\section{Research method}

The study focused on how emergency response organizations can enhance citizen response. The research questions were: (RQ1) How do experts view the state of the art in encouraging citizen response in the EU member states? (RQ2) What suggestions do experts offer for increasing citizen response? (RQ3) What do they see as examples of best practices in enhancing citizen response?

The data were gathered via an online questionnaire, consisting of a few closed, but mostly open-ended, questions. The participants' background was ascertained. To determine the state of the art (RQ1), the experts were asked about how citizen response is encouraged, if citizens are involved in crisis preparedness, and what citizen groups were involved in crisis preparedness activities. To obtain suggestions for increasing citizen response (RQ2), questions were asked about where potential was seen to further involve citizen groups, and what is needed to further enhance the response abilities of the public. 
To elicit examples of best practices (RQ3), a question was included on inspiring examples that have increased citizen response.

The target group were emergency management and crisis communication experts drawn from the database of an international crisis management conference, the International Disaster and Risk Conference (IDRC) in Davos Switzerland. Participants, who were asked for their informed consent beforehand, received a login code to be able to return to the questionnaire if they wanted to add information later. The questionnaire was piloted and small revisions made based on the feedback received.

The researchers made sure that the responses could not be identified and the anonymised data were kept in a password-protected computer environment at the university. The responses were analyzed from a data-driven perspective using qualitative content analysis (e.g. Frey et al., 2000). The data were downloaded to ATLAS.ti (qualitative data analysis software) and the authors familiarized themselves with the data by repeated reading. Background information statistics and multiple choice questions were calculated quantitatively. The next step was a qualitative analysis of the answers to the open questions. The data were read several times to enable categorization and thematisation. Under each theme, following the questions, similar topics were grouped together. They were further subdivided into subtopics from a data-driven perspective, brought together in overviews, and summarized in tables. The emphasis was on collaboration by response organizations with citizens and facilitating citizen response in the various crisis phases through communication (Hyvärinen and Vos, 2015). Where differences between views were found, we returned to the data to deepen the analysis. This showed, that participants who (also) had experience outside the EU cited different examples and often presented different views. To further illuminate the differences we split up the relevant tables accordingly. The related conclusions are indicative and could be further tested in studies with larger numbers of participants.

The questionnaire also included other questions, on issues such as terrorism communication, which are not reported in this paper. The long questionnaire was emailed to 493 experts, of whom 42 answered the section on public empowerment initiatives by response organisations, the focus of the present paper. Contacts during the IDRC conference indicated that non-response may have been caused by the login requirement enabling respondents to finish completing the lengthy questionnaire at a later time. Following strict ethical guidelines, the participants were free to leave any question open, e.g. if they were not familiar with its content. This paper presents research data on the work experience and views of the participating experts, obtained from answers to six, mostly qualitative, questions on the promotion of citizen response in crisis situations.

\section{Participants}

Of the 42 participants, 15 were experts in crisis or emergency management, 12 were experts in crisis communication, and the others worked in related fields, including risk analysis, assessment and management, disaster reduction and management policy, recovery planning, and public education for disaster prevention. They had many years of experience in the field (mean 11.7 years).

The types of organisations represented by the experts were mostly governmental organisations, centres of expertise or research institutions, enterprises and nongovernmental organisations (see Table 1). 
Table 1 Participants by type of organisation

\begin{tabular}{|l|c|}
\hline Type of organisation & $\begin{array}{l}\text { Number of } \\
\text { respondents }\end{array}$ \\
\hline $\begin{array}{l}\text { Governmental organisation (e.g. } \\
\text { municipality, ministry, authority) }\end{array}$ & 22 \\
\hline Police or rescue services & 1 \\
\hline Health care & 11 \\
\hline $\begin{array}{l}\text { Expertise centre or Research } \\
\text { organization }\end{array}$ & 6 \\
\hline $\begin{array}{l}\text { Non-governmental organization } \\
\text { (e.g. Red Cross) }\end{array}$ & 8 \\
\hline Enterprise (e.g. energy company) & 6 \\
\hline Other ${ }^{\mathrm{a}}$ & $55^{\mathrm{b}}$ \\
\hline Total
\end{tabular}

a) UN, UN Agency (UNDP), Telecommunications, Private Consultant, R\&D Center, County fire brigade

b) Multiple answers were permitted $(\mathrm{N}=42)$

The participants represented organisations operating on different levels: 13 organisations worked internationally, 18 nationally, 5 regionally, and 8 locally. Most of the participants worked in one or more member states of the European Union (EU), whereas 5 worked only outside the EU in developing countries, and 2 worked both inside and outside the EU. Where the data showed differences, these are indicated.

\section{Findings}

Below, the views of the participants on the state of the art in enhancing citizen response are presented. Next, their views on how to further enhance citizen response are addressed, followed by what they consider to be best practices.

\subsection{Ways to encourage citizen response}

The item inquiring how citizen response is currently being encouraged in the participants' countries was answered by choosing from one of six response options: (a) Preparedness campaigns on the national level, (b) Preparedness campaigns on the regional or local level, (c) Educational activities by schools and volunteer groups or associations, (d) Cooperation with citizen groups to develop resilience on the local level, (e) Exercises in various emergency scenarios involving citizen groups, and (f) Other (please specify).

According to the answers given by the participants, preparedness campaigns on the regional or local level and on the national level were the most common ways to enhance citizen response. Educational activities by schools and volunteer groups or associations, cooperation with citizen groups to develop resilience on the local level, and exercises in various emergency scenarios involving citizen groups were also frequently mentioned. Other ways were: "exercises with companies within an industry segment"; "corporate rehearsals and tests"; "public-private partnership collaboration at the local level"; "sharing of plans with stakeholders"; and "strengthening volunteer involvement in rescue organisations". Table 2 shows the variety of tools and approaches used to promote citizen engagement. 
Table 2 How citizen response is currently encouraged in the participants' area of operations

\begin{tabular}{|l|c|c|c|}
\hline \multirow{2}{*}{ Ways to enhance citizen response } & \multicolumn{3}{|l|}{$\begin{array}{l}\text { Frequency of mentions } \\
\text { according to main area of operations }\end{array}$} \\
\cline { 2 - 4 } & European Union & $\begin{array}{c}\text { Combination or } \\
\text { other }\end{array}$ & All ${ }^{\text {b) }}$ \\
\hline $\begin{array}{l}\text { Preparedness campaigns on the regional or local } \\
\text { level }\end{array}$ & 22 & 8 & 30 \\
\hline Preparedness campaigns on the national level & 20 & 6 & 26 \\
\hline $\begin{array}{l}\text { Educational activities by schools and volunteer } \\
\text { groups or associations }\end{array}$ & 15 & 6 & 21 \\
\hline $\begin{array}{l}\text { Cooperation with citizen groups to develop resilience } \\
\text { on the local level }\end{array}$ & 11 & 7 & 18 \\
\hline $\begin{array}{l}\text { Exercises in various emergency scenarios involving } \\
\text { citizen groups }\end{array}$ & 13 & 4 & 17 \\
\hline Miscellaneous a) & 5 & 0 & 5 \\
\hline
\end{tabular}

a) Exercises with companies within an industry segment; Corporate rehearsals, tests; Public-Private partnership collaboration at local level; Sharing of plans with stakeholders; Strengthening volunteer involvement in rescue organisations

b) Multiple answers were permitted $(n=40)$

Seen from the perspective of the participants' main area of operations, developing resilience via local level cooperation with citizen groups seems to be the most common way to enhance citizen response in the non-EU countries, whereas the participants working mainly in EU countries mentioned this approach least often and listed preparedness campaigns as the main way of addressing this objective. However, owing to the small sample size, such comparisons must be viewed with caution.

\subsection{Involvement of citizen groups in crisis preparedness}

The next section of the questionnaire focused on community approaches to crisis preparedness. The first question here was: "Are citizen groups currently involved in crisis preparedness by your organisation? If so, please also explain in what ways this is done."

This question yielded 21 responses that were coded into three categories (yes; yes to some extent; and no, why not?) and according to the main area of operations of the participant. A rather large number of the participants (11) answered by stating that citizen groups were not involved in crisis preparedness by their organisation at all. Some answers showed that the participant considered current activities in promoting citizen response insufficient, or it was mentioned that this was being done by or in cooperation with other agencies (see Table 3). 
Table 3 Involvement of citizen groups in crisis preparedness by participants’ organisations

\begin{tabular}{|c|c|c|}
\hline $\begin{array}{l}\text { Are citizen groups } \\
\text { involved by the partici- } \\
\text { pant's organisation? }\end{array}$ & $\begin{array}{l}\text { Main area of operations: } \\
\text { European Union }\end{array}$ & $\begin{array}{l}\text { Main area of operations: } \\
\text { Combination or other }\end{array}$ \\
\hline $\begin{array}{l}\text { Yes. What is being } \\
\text { done to involve citizen } \\
\text { groups? }\end{array}$ & $\begin{array}{l}\text { Including citizens in disaster } \\
\text { exercises } \\
\text { Integration of (organized) } \\
\text { citizen groups in crisis plans } \\
\text { Involving citizens via NGOs, } \\
\text { policy makers, and advisory } \\
\text { boards } \\
\text { Provision of educational } \\
\text { material for children } \\
\text { Local disaster risk reduction } \\
\text { and emergency management } \\
\text { teams } \\
\text { Expert workshops, events, } \\
\text { and conferences for exchange } \\
\text { of best practices } \\
\text { Citizens involvement in } \\
\text { frontline incident response, } \\
\text { planning, recovery }\end{array}$ & $\begin{array}{l}\text { Including citizens in disaster drills } \\
\text { Provision of preparedness information } \\
\text { for citizens } \\
\text { Participative approach to identifying } \\
\text { risks, vulnerability, and capacities } \\
\text { Preparedness process is made visible to } \\
\text { citizens } \\
\text { Educational activities in schools in } \\
\text { cooperation with emergency services } \\
\text { Voluntary committees involved in } \\
\text { planning and implementation of disaster } \\
\text { risk reduction activities } \\
\text { Efforts made to increase community } \\
\text { awareness of risks } \\
\text { Joint research projects and programmes }\end{array}$ \\
\hline $\begin{array}{l}\text { Yes, to a limited extent. } \\
\text { What is being done? }\end{array}$ & $\begin{array}{l}\text { Informing publics, e.g. via } \\
\text { presentations and handouts on } \\
\text { emergency preparedness } \\
\text { Involvement is implemented } \\
\text { in cooperation with other } \\
\text { government agencies, or e.g. } \\
\text { via community council } \\
\text { meetings } \\
\text { Debriefings are organized for } \\
\text { citizens }\end{array}$ & $\begin{array}{l}\text { Citizens are involved only via partner } \\
\text { NGOs }\end{array}$ \\
\hline No, why not? & $\begin{array}{l}\text { Not a priority or role of the } \\
\text { organisation }\end{array}$ & \\
\hline
\end{tabular}

According to the participants whose main area of operations was within the EU, citizen involvement in crisis preparedness was implemented by organizing exercises and integrating them in crisis plans. This mostly applied to organized volunteers, who are given a supporting role in, e.g., helping in evacuations and providing psycho-social support. Involvement is generated via NGO memberships (e.g. Red Cross), via the deployment, support and training of local disaster risk reduction and emergency management teams, via stakeholder groups and via incident response, planning, and recovery. 
Some organisations exchanged best practices in expert workshops, events, and conferences. Some were active in contacting political actors, authorities, or other actors, such as scientific and operational advisory boards. Educational material, aimed mostly at children, was also produced. Engagement was also promoted by attending community council meetings, giving presentations, and issuing handouts on emergency preparedness. Only one participant gave a clear example of an interactive approach, viz. a residents' meeting after a crisis situation, which could also prepare citizens for future similar events.

According to the participants who mainly operated outside the EU, citizen groups were involved in drills (e.g. mass tsunami early warning and evacuation), along with the provision of preparedness information, and educational activities implemented in schools in cooperation with emergency services. Community- and civil society-based local, voluntary committees were involved in the planning and implementation of disaster risk reduction (DRR) activities. However, some of these participants mentioned that citizen groups were only involved via partner NGOs. Involvement was also promoted by making the preparedness process visible via community awareness and by identifying risks, vulnerability, and capacities by means of a participatory approach. Communication had a key role in many of the actions taken to involve citizens.

One participant explained the importance of communication in empowering citizens to take action in the case of an emergency thus: "a clear line of communication from agencies describes how preparing is necessary because in a time of crisis, emergency management personnel or equipment may not be available to help everyone, so preparing can reduce their dependence on agency assistance."

These results indicate that citizen groups in Europe are involved on very different levels. Some groups are organized in volunteer organisations, while for others involvement is not systematic. Many organisations are not in direct contact with citizen groups, or see citizen involvement in preparedness as one-way communication, such as dissemination of information through presentations and handouts.

\subsection{Citizen groups included in crisis preparedness}

The next question was: "Please list the citizen groups your organisation is cooperating with in crisis preparedness, e.g. those groups mentioned in crisis plans.” This question yielded 21 responses (see Table 4). As the responses yielded more groups than citizen groups alone, these were coded as follows: citizen groups, governmental actors, private sector, and formal or informal networks.

The responses were later organized in two categories "European Union" and "Combination or other" based on the main area of operations of the participant. There were few differences between these two categories of participants. Both mentioned NGOs, particularly the Red Cross, the private sector, social bodies such as youth groups, and disaster councils or committees. However, those operating mainly in the EU more often named governmental actors, whereas those operating (also) outside of the EU more often mentioned informal and formal networks such as the OECD High Level Risk Forum. 
Table 4 Citizen groups that the participants' organisations cooperate with in crisis preparedness by the main area of operations of the participants

\begin{tabular}{|c|c|c|}
\hline & $\begin{array}{l}\text { Main area of operations: } \\
\text { European Union }\end{array}$ & $\begin{array}{l}\text { Main area of operations: } \\
\text { Combination or other }\end{array}$ \\
\hline $\begin{array}{l}\text { Citizen } \\
\text { groups } \\
\text { mentioned }\end{array}$ & $\begin{array}{l}\text { Social bodies, e.g.: } \\
\text { - Youth groups } \\
\text { - Students } \\
\text { NGOs and voluntary organisations, e.g.: } \\
\text { - } \quad \text { Red Cross } \\
\text { - Voluntary rescue services } \\
\text { - International risk governance } \\
\text { councils } \\
\text { Community and town councils }\end{array}$ & $\begin{array}{l}\text { Social groups, e.g.: } \\
\text { - General public } \\
\text { - Women's groups } \\
\text { - } \quad \text { Youth groups } \\
\text { Disaster risk committees } \\
\text { Village health workers } \\
\text { NGOs and voluntary organisations, e.g. } \\
\text { • Local Red Cross volunteers } \\
\text { “All knowledgeable members of the } \\
\text { community” }\end{array}$ \\
\hline $\begin{array}{l}\text { Public } \\
\text { sector }\end{array}$ & $\begin{array}{l}\text { Blue light services } \\
\text { Ministries } \\
\text { Municipalities } \\
\text { Federal agencies } \\
\text { State agencies } \\
\text { Regional agencies } \\
\text { Municipal agencies }\end{array}$ & $\begin{array}{l}\text { Disaster management working groups at } \\
\text { different levels } \\
\text { Emergency units }\end{array}$ \\
\hline $\begin{array}{l}\text { Private } \\
\text { sector }\end{array}$ & $\begin{array}{l}\text { Private companies (e.g. engineering and } \\
\text { civil jobs specialist) }\end{array}$ & "Partners in all sectors" \\
\hline $\begin{array}{l}\text { Formal or } \\
\text { informal } \\
\text { networks }\end{array}$ & $\begin{array}{l}\text { Private sector Lessons-learned networks } \\
\text { in crisis management } \\
\text { Platform of the regional chiefs of staff } \\
\text { OECD High Level Risk Forum } \\
\text { Global Risk Forum }\end{array}$ & $\begin{array}{l}\text { Academia } \\
\text { Research groups, scientists }\end{array}$ \\
\hline
\end{tabular}

Although cooperation with various citizen and other groups was mentioned, one participant pointed out that although in a crisis situation cooperation with social groups is possible, it is "not always incorporated in the organisation's emergency plans". If this is common practice, it demonstrates that inclusion of citizens in preparedness activities is not customary and therefore needs to be taken into greater consideration on the strategic level. Some organisations did not cooperate with any citizen groups: "We exclusively communicate with authorities so far."

\subsection{Potential to further involve citizens}

The next question was: "Where do you see potential to further involve citizen groups?" This question generated 28 answers. The responses offer a variety of possibilities for furthering citizen involvement in crisis preparedness and response. Some mentioned specific groups, while others discussed activities that could or needed to be done in order to further involve citizens (see Table 5). 
Table 5 Areas with potential for further involvement of citizen groups, as suggested by the participants

\begin{tabular}{|c|c|c|}
\hline & $\begin{array}{l}\text { Main area of operations: } \\
\text { European Union }\end{array}$ & $\begin{array}{l}\text { Main area of operations: } \\
\text { Combination or other }\end{array}$ \\
\hline $\begin{array}{l}\text { Awareness } \\
\text { raising }\end{array}$ & $\begin{array}{l}\text { Residents' meetings, and } \\
\text { neighbourhood involvement } \\
\text { Participative risk assessments and } \\
\text { mapping } \\
\text { Risk education }\end{array}$ & $\begin{array}{l}\text { Participative risk mapping, } \\
\text { monitoring, and low cost management } \\
\text { Early warning systems } \\
\text { linking preparedness and response in } \\
\text { coordination with government levels }\end{array}$ \\
\hline $\begin{array}{l}\text { Prepared- } \\
\text { ness edu- } \\
\text { cation and } \\
\text { drills }\end{array}$ & $\begin{array}{l}\text { Exercises for various emergency } \\
\text { scenarios with various stakeholders } \\
\text { Training and educating local people } \\
\text { Integrating preparedness education in } \\
\text { school curricula } \\
\text { Programmes }\end{array}$ & $\begin{array}{l}\text { Expanding local voluntary disaster risk } \\
\text { committees } \\
\text { Preparedness plans, } \\
\text { decision making, and planning by authorities } \\
\text { Regular, annual community-wide disaster } \\
\text { drills }\end{array}$ \\
\hline $\begin{array}{l}\text { After } \\
\text { crises }\end{array}$ & Lessons learned, evaluation of real crises & \\
\hline Other & $\begin{array}{l}\text { Health prevention programmes } \\
\text { Social media }\end{array}$ & \\
\hline $\begin{array}{l}\text { Different } \\
\text { actors/ } \\
\text { groups } \\
\text { mentioned }\end{array}$ & $\begin{array}{l}\text { Volunteer groups or associations } \\
\text { Schools and universities } \\
\text { Private, cultural, and professional } \\
\text { associations } \\
\text { Immigrants } \\
\text { Religious groups } \\
\text { Industry segments, businesses }\end{array}$ & Community emergency response teams \\
\hline
\end{tabular}

The findings indicate that exercises and drills, learning from real crises, and preparedness education are considered important in further involving citizen groups. Engagement of citizens for crisis response should, according to the participants, begin already at school. Utilizing social media was also suggested as a way to further involve citizens, as there is a potential for communication "via social media, e.g. Facebook, Twitter". As stated by the participants, different levels of the community - local, regional, municipal, and neighbourhood - need to be taken into account and actions performed accordingly.

The participants saw a need to include citizens and other stakeholder groups to a larger extent in preparedness activities. In the pre-crisis phase, more participative risk mapping involving citizens and more risk awareness education were called for. Preparedness education was also emphasized as a basis for a better "understanding of warning messages" and more effective "behaviour during disasters". Education should start already at school and should be integrated into the curriculum.

In mounting exercises, continuity is called for. Emergency drills and training should be regular, e.g. annual, and include participation of various stakeholder groups. These activities have many benefits according to the participants: they are multi-sector, cooperative, and collaborative. Familiarity makes them more sustainable over generations. Drills are scalable according to level (local, regional etc.), and can be made more realistic 
over time. They are opportunities to practice response and discover weaknesses in risk reduction. Drills involving multiple stakeholders are also opportunities to create trust and strengthen the partnerships needed in crisis situations. One participant remarked that drills need to be dynamic because when they are inadequately executed such efforts can be "squandered and rendered meaningless".

According to some of the participants, the perceptions of citizen groups should be included in decision making and in developing policies: "More efforts should focus on decision making. Strengthening capacities of local leaders to link preparedness plans ... by communities groups to authority planning is essential to take into consideration the needs of communities."

Another participant also raised the issue of connecting different levels: "Most of our work is done on and most members are positioned on the national level, while most 'normal' citizens' initiatives are organized on the local or regional level." This indicates that coordination between various actors on different levels is needed.

Citizens can also be involved indirectly; as one participant put it: "Citizens' initiatives working on larger scale (national level) are mostly organized in associations or societies that are working for special groups like voluntary fire brigades or technical assistance. Some of these groups are members in our organisation, but we do not call them citizens' initiatives anymore. So in my country this is a special system and many citizens are involved only in an indirect relation via many different levels or steps in between."

One participant said that citizen groups can be groups of people living near one another, or civil organisations. The groups that need to be addressed and involved in the preparedness measures should be clarified at the policy-making level.

\subsection{How to further enhance response abilities of the public}

Below, we present the answers to this open question: “According to your view, what is mostly needed in your country to further enhance the crisis response abilities of the public?”

29 answers were given to this question. The answers were organized according to the following themes found in the data: (1) Preparedness activities and education, (2) Communication campaigns and technology, (3) Supporting community spirit and thinking, and (4) Policies. The responses were also arranged according to the main working area of the participants. The findings of this question are gathered in Table 6 .

Table 6 What the participants considered is mostly needed to further enhance the crisis response abilities of the public

\section{Preparedness activities and education}

- Education in risk awareness, preparedness, and resilience, including schools and universities

- Public education, teaching citizens how to become part of the solution

- Bringing disaster knowledge to the local and national level

- Intensifying training efforts for local disaster risk committees

- Making vulnerability maps, initiating national working groups

\section{Communication campaigns and technology}

- Sustainable, objective, and regular information in all the phases of a crisis, including post-disaster communication

- Use of social influencers on a personal level, and broad public campaigns

- Receiving and giving feedback, building trust among stakeholders 
- $\quad$ Ability to meet information needs of citizens and of media, in a timely way and repeatedly

- Helping people find relevant information in a way that does not strain the emergency communications queue

- Early alert technologies and multi-channel alerting systems

- Technology for knowledge transfer

- Monitoring systems and indicators for evaluation

3. Supporting community spirit and thinking

- Motivation and willingness of politicians to educate the population

- Integrating citizens into preparedness activities

- Discussion between authorities and citizens about preparedness and response to crises

- Creating ownership at the grassroots level and creating a level of support between local communities and local authorities

- Government support and opportunities to engage directly with crisis managers and crisis communicators

\section{Policies}

- Development of policies, communications, and services for civil contingencies, involving governments and the responder community

- Harmonizing the local response with the national response in accordance with international guidelines

- Governments to promote citizen involvement on a global level

- $\quad$ An integrative system approach that includes all levels of the community

- Funding to support local initiatives and new approaches

According to the participants, empowerment of citizens needs to start in the preparedness phase by raising public awareness via campaigning, education on risks and preparedness, teaching survival skills, offering instructions, and creating trust among stakeholders. Consistency and repeated communication are needed, while all levels of the community should be included: city, department, region, country, and continent or global. In addition, technology, knowledge transfer, monitoring systems, and clear indicators for evaluation were called for. Moreover, funding is needed to support local initiatives, develop new approaches, and enable area-wide integration.

\subsection{Best practices in enhancing citizen response}

This section presents the findings on best practices in enhancing citizen response. This includes responses to this open-ended question: "Please describe one or two examples you consider inspirational best practices for enhancing citizen response, web links are appreciated.” The aim was to clarify the directions suggested by the experts for increasing citizen response. 23 examples of best practices were given, including 15 website links. The websites mentioned by the participants were investigated to see what kinds of activities were considered best practices by the experts. Following a division of various approaches (as proposed by the IFRC, 2011), the examples given by the participant were assigned to three categories (see Table 7):

- Engagement programmes, enhancing citizen preparedness and participatory learning aimed at disaster risk reduction on the local level. 
- Informal and formal education, involving communities or schools, often using standardized materials that may be adjusted to the needs and concerns of local audiences.

- Educative campaigns, aiming at preparedness on the national, regional, or local level.

The examples of good practices enhancing citizen response were mostly in the first category, indicating that the experts valued engagement programmes above the other categories.

Participants working mainly in the EU gave examples of all three approaches, while those working in a combination of countries or mainly outside the EU focused on engagement programmes only. The examples given by the latter group were also more interactive.

The engagement programmes mentioned by participants working mainly in the EU included websites facilitating collaboration with authorities or offering instructive one-way information for citizens and authorities. The informal and formal education mentioned as good examples by them, also mostly comprised one-way educative materials for particular crisis scenarios, along with directions for action, although some interactive elements were also mentioned, including a school drill. One educative campaign included a variety of activities. Participants working in as well as outside EU, or mainly outside the EU, mentioned fewer engagement initiatives; however, these were more often aimed at citizens and volunteers.

Although the role of social media in emergency communication is increasing, it was not widely present in the examples given. One example was directly linked to a Facebook page; however, the link had expired. In some website examples, sharing via social media was made easy for users.

In particular, the concrete examples provided by experts working in the EU contained little interaction and citizens were not involved in producing the content. This may indicate, consistent with the remarks by the participants reported earlier, that best practices of this kind are in short supply.

Table 7 Examples of best practices as given by the participants

\section{Programmes for enhancing citizen involvement and participatory learning}

Main area of operations: European Union

\section{Das Hochwasserportal:}

Web info for flood-prone areas in Germany based on citizen input, aimed at citizens and local authorities.

\section{The future of UK resilience:}

Forum for joint development of resilience strategies in natural hazards and civil emergencies by various response organisations.

\section{Fachinformationen Hochwasser:}

Data related to flood, level and flow provided by authorities can be accessed on the Internet, by emergency officials and citizens.

\section{Krisinformation.se:}

Swedish national website for emergency information describing how emergency management works. In an emergency, a special page is set up to provide the public with guidance on how to find information. 


\begin{tabular}{|c|c|}
\hline & $\begin{array}{l}\text { RIMAComm Hazard Potential \& Self-protection: } \\
\text { Integrated multi-hazard risk analysis for municipalities in Tyrol for } \\
\text { municipalities and citizens. }\end{array}$ \\
\hline \multirow{4}{*}{$\begin{array}{l}\text { Informal and formal } \\
\text { education } \\
\text { Main area of operations: } \\
\text { European Union }\end{array}$} & $\begin{array}{l}\text { Evacuation drill: } \\
\text { Large scale drill in evacuation of primary schools in the event of a } \\
\text { nuclear and radiological emergency in Belgium, accompanied by } \\
\text { educative materials prepared by the teachers. }\end{array}$ \\
\hline & $\begin{array}{l}\text { FONES: } \\
\text { Various downloadable brochures for citizens and companies by the } \\
\text { Swiss federal authority on crisis preparedness and acting during } \\
\text { crises. }\end{array}$ \\
\hline & $\begin{array}{l}\text { SPEK: } \\
\text { Website hosted by Finnish rescue services offering education for } \\
\text { organisations and citizens via guides and instructions for } \\
\text { preparedness and acting in emergencies. }\end{array}$ \\
\hline & $\begin{array}{l}\text { Cold weather plan for England: } \\
\text { Materials part of wider measures to protect individuals and } \\
\text { communities from the effects of severe winter weather for (the use } \\
\text { of) health care and local authorities, citizens, and voluntary sector } \\
\text { organisations. }\end{array}$ \\
\hline $\begin{array}{l}\text { Educative campaigns } \\
\text { Main area of operations: } \\
\text { European Union }\end{array}$ & $\begin{array}{l}\text { School campaign: } \\
\text { Campaign for 8th graders to learn to prevent and act in emergency } \\
\text { situations, in cooperation with emergency services, authorities, and } \\
\text { private partners, including e.g. an insurance company. }\end{array}$ \\
\hline \multirow{5}{*}{$\begin{array}{l}\text { Programmes for enhancing } \\
\text { citizen involvement and } \\
\text { participatory learning } \\
\text { Main area of operations: } \\
\text { Combination or other }\end{array}$} & $\begin{array}{l}\text { A community-based flood warning system: } \\
\text { System in the Buzi River Basin of Mozambique, run for citizens by } \\
\text { educated volunteers. }\end{array}$ \\
\hline & $\begin{array}{l}\text { Making Beira Resilient to Floods and Cyclones: } \\
\text { Educating volunteers to take action during floods and cyclones. }\end{array}$ \\
\hline & $\begin{array}{l}\text { Neighbourhood Disaster Volunteers Foundation: } \\
\text { Information for Turkish volunteers to reduce disaster risks in their } \\
\text { area, arrange first response and contribute to recovery. }\end{array}$ \\
\hline & $\begin{array}{l}\text { SVP Volontaire: } \\
\text { Event for volunteer associations and authorities to come together to } \\
\text { promote international cooperation and dialogue between institutions } \\
\text { and civil society on volunteering. }\end{array}$ \\
\hline & $\begin{array}{l}\text { Shake Out: } \\
\text { Earthquake drill that anyone can participate in to prepare and } \\
\text { practice, with local or regional coordination by an emergency } \\
\text { management agency or alliance. }\end{array}$ \\
\hline
\end{tabular}

In some cases, rather than mentioning precise examples with links, the participants gave more general examples; these more often included the participation of citizens. As good practices in participatory learning, the participants mentioned full-size drills and national exercises involving actors from many sectors. Preparedness activities were also mentioned, such as preparing for avian flu, which would require a worldwide exercise next to actions at the country level. The Haiti disaster and Japan tsunami relief efforts were mentioned as two specific cases of this type. 
Integration in education activities was viewed positively, as also was disseminating information from one generation to another. One participant was inspired by the idea of "involving people in form of round tables to develop ideas and put these into practice by monetary restrictions or incentivizing people to do something”.

Increasing public awareness by using local media or mobile phone services was considered a good initiative by one participant, as it helps disseminate preparedness information and warnings, and also supports the sharing of information by communities. Meetings of residents after emergencies were also mentioned: "So called 'safety walks' with citizens. Their purpose is to walk through the living hood and check it by how it looks from the safety (perspective)." One participant pointed out that "there should be no best practices - only situation-specific practices”, as a best practice in one case can be a bad practice in another.

\section{Conclusions}

The results indicate that, among the experts participating in this study, awareness of the importance of involving citizen groups in crisis management activities is high. Despite this overall awareness, the results give a very diverse picture of the actual implementation of a community approach to crisis management.

It seems that practitioners are currently in the midst of implementing actions for increasing citizen response. While, owing to the limited number of participants, the state of the art cannot be fully known on the basis of this research the results indicate a fragmented approach and a lack of structural attention to enhancing citizen response. The data show that it is not enough to focus solely on the individual level through preparedness campaigns; instead, continuous collaboration with community groups and organisations on the local, national, and international level also needs to be taken into account.

This paper recognizes that individual and community involvement is critical to disaster preparedness and response. In addition, it underlines that policy makers should also consider cultural and regional differences within the European Union. Country- and region-specific approaches need to be developed simultaneously. Risk awareness and sense of community are not equally strong in all regions. As one participant put it, "there is a big difference between emerging regions, where disasters and crises happen more often and with dramatic impact on people and economies. There professionals need support to enforce their reactiveness (material, training, staff). The public on the other hand is quite aware of the risk and people help each other in the communities. This is different in developed countries, where professionals have staff, material and knowledge. However, the public is not at all aware of the risks and therefore would be completely overwhelmed in case of an emergency. Here the focus needs to be risk awareness and preparation."

In developed countries, citizens may think that it is the job of the authorities to provide and maintain security. However, their own engagement is needed for disaster preparedness and mitigation. Now is a good time to stimulate exchange of best practices on communication tools and strategies for enhancing community resilience and build a model for more general application. As one participant proposed, it is "vitally important to improve communication - evaluation of outcomes of communication actions is now urgently needed”.

The objective of this study was to explore the views of experts on enhancing citizen response. The results derived from the data can only be generalized with caution because of the small number of participants (42). However, while small in comparison to the potential population of experts, the original distribution of the questionnaire was to experts 
attending in an International Disaster and Risk Conference. This raises the level of credibility of the results compared to the use of a simple convenience sample, as indicated by the respondents' mean level of experience in the field (mean 11.7 years).

The results are beneficial to those involved with policy and programme development aimed at ensuring individual and community preparedness. They show that in the European Union the level of attention paid to community approaches in crisis management seems to vary widely and that experience in implementing such approaches is rather limited. Therefore, the findings call for further investigation of the enablers and barriers involved. In places were collaboration has been established, it would be important to learn how exactly this is facilitated, and what tools and communication competences are called for. This would offer experts in the field and policymakers concrete insights that can assist in furthering collaboration with, and the overall crisis preparedness of, citizens.

This study provides the first overall picture of expert views on the status of public empowerment and the challenges experienced in enhancing citizen response in the European Union. It indicates that the situation is currently fragmented and lacks a broader experience with community approaches to crisis management as well as structural involvement of citizen groups in preparedness activities. There is a need for an integral approach, taking all the relevant actors, including citizens, into account. The approach taken needs to match the specific needs and beliefs of all the relevant citizen groups, and be able to respond to the various emergencies the target region is prone to.

\section{Acknowledgements}

This study is part of the research project Public Empowerment Policies for Crisis Management that has received funding from the European Community's Seventh Framework Programme (FP7/2007-2013) under grant agreement $\mathrm{n}^{\circ} 284927$.

\section{References}

Boon, H.J., Cottrell, A., King, D., Stevenson, R.B. and Millar, J. (2012) 'Bronfenbrenner’s bioecological theory for modelling community resilience to natural disasters' Natural Hazards, Vol. 60, No. 2, pp.381-408.

Danielsson, E. (2014) 'From common operating picture to situational awareness' International Journal of Emergency Management, Vol. 10, No. 1, pp.28-47.

Dynes, R.R. (1994) 'Community emergency planning: False assumptions and inappropriate analogies' International Journal of Mass Emergencies and Disasters, Vol. 12, No. 2, pp.141158.

Eiser, R.J., Bostrom, A., Burton, I., Johnston, D.M., McClure, J., Paton, D., Van der Plight, J. and White, M.P. (2012) 'Risk interpretation and action: A conceptual framework for responses to natural hazards’ International Journal of Disaster Risk Reduction, Vol. 1, pp.5-16.

Etkin, D. and Timmermans, P. (2013) 'Emergency management and ethics’ International Journal of Emergency Management, Vol. 9, No. 4, pp.277-297.

FEMA (2011a) A whole community approach to emergency management: Principles, themes, and pathways for action Federal Emergency Management Agency, New York, http://www.fema.gov/library/viewRecord.do?id=4941 (Accessed on 29 December 2012).

FEMA (2011b) Universal access to and use of information: Long-term trends and drivers and their implications for emergency management Federal Emergency Management Agency, New York, 
http://www.fema.gov/library/viewRecord.do?fromSearch=fromsearch\&id=6030 (Accessed on 11 June 2013).

Frey, L.R., Botan, C. H. and Kreps, G.L. (2000). Investigating communication: An introduction to research methods (2nd ed.) Allyn \& Bacon, Needham Heights, MA.

Helsloot, I. and Ruitenberg, A. (2004) 'Citizen response to disasters: A survey of literature and some practical implications’ Journal of Contingencies and Crisis Management, Vol. 12, No. 3, pp.98-111.

Hyvärinen, J. and Vos, M. (2015) 'Developing a conceptual framework for investigating communication supporting a community approach to crisis management' Societies, Vol. 5, No. 3, pp.583-597.

IFRC (2011) Public awareness and public education for disaster risk reduction: A guide International Federation of Red Cross and Red Crescent Societies, Geneva, http://www.ifrc.org/Global/Publications/disasters/reducing_risks/302200-Public-awarenessDDR-guide-EN.pdf (Accessed on 29 May 2013).

Linnell, M. (2014) 'Citizen response in crisis: Individual and collective efforts to enhance community resilience’ Human Technology: An Interdisciplinary Journal on Humans in ICT Environments, Vol. 10, No. 2, pp.68-94.

Long, M.E., Brooks, B.P., Morabito, P.N., Schneider, J.L. and Pardee, J.W. (2014) 'The relationship between social and hierarchical communication networks in rural emergency response' International Journal of Emergency Management, Vol. 10, No. 2, pp.122-134.

Norris, F.H., Stevens, S.P., Pfefferbaum, B., Wyche, K.F. and Pfefferbaum, R.L. (2008) 'Community resilience as a metaphor, theory, set of capacities, and strategy for disaster readiness’ American Journal of Community Psychology, Vol. 41, No. 1, pp.127-150.

Palen, L., Vieweg, S., Liu, S.B. and Lee Hughes, A. (2009) 'Crises in a networked world: Features of computer-mediated communication in the April 16, 2007, Virginia Tech event' Social Science Computer Review, Vol. 27, No. 4, pp.467-480.

Palenchar M.J. and Heath, R.L. (2007) 'Strategic risk communication: Adding value to society' Public Relations Review, Vol. 33, pp.120-129.

Perry, R.W. and Lindell, M.K. (2003) 'Understanding citizen response to disasters with implications for terrorism’ Journal of Contingencies and Crisis Management, Vol. 11, No. 2, pp.49-60.

Romo-Murphy, E. and Vos, M. (2014) 'The role of broadcast media in disaster preparedness education; lessons learned in the scientific literature 2002-2012’ Media Asia, Vol. 41, No. 1, pp.71-85.

Seeger, M.W. (2006) 'Best practices in crisis communication: an expert panel process' Journal of Applied Communication Research, Vol. 34, No. 3, pp. 232-44.

Seeger, M.W. and Sellnow, T.L. (2013) Theorizing crisis communication Whiley-Blackwell, West Sussex.

UNISDR (2011) 2011 Global assessment report on disaster risk reduction: Revealing risk, redefining development United Nations ISDR, Geneva.

Veil, S.V. and Husted, R.A. (2012) 'Best practices as an assessment for crisis communication' Journal of Communication Management, Vol. 16, No. 2, pp.131-145.

Yee, S.S., Wardell, C. III and Thorkildsen, Z. (2012) Social media in the emergency management field 2012 - Survey Results, http://www.cna.org/sites/default/files/research/SocialMedia_EmergencyManagement.pdf (Accessed on 6 June 2013). 